\title{
Afet Politikalarında Risk Unsuru ve Afet Mevzuatında Risk Yönetimi
}

\author{
Risk Factor in Disaster Policy and Risk Management in Disaster Legislation
}

\author{
Gülcan AZIMLİ ÇILİNGíR \\ Dr. Arş. Gör., Van Yüzüncü Yıl Üniversitesi, \\ İ̈F, Kamu Yönetimi Bölümü, \\ gulcanazimlicilingir@yyu.edu.tr \\ https://orcid.org/0000-0002-3618-2104

\section{İlke ÖRÇEN GÜLER} \\ Dr. Arş. Gör., Van Yüzüncü Yll Üniversitesi, \\ İ̈BF, Kamu Yönetimi Bölümü, \\ ilkeorcen@yyu.edu.tr \\ https://orcid.org/0000-0002-8755-609X
}

\author{
Makale Başvuru Tarihi: 11.02.2020 \\ Makale Kabul Tarihi: 06.05.2020 \\ Makale Türü: Araştırma Makalesi
}

\begin{abstract}
ÖZET
Afetler neden olduklarl can kaylplar yaninda ekonomik ve toplumsal yapiya verdikleri zararlar nedeniyle tarih boyunca insanlı̆̆ın en önemli sorunlarından biri olmuştur. Literatürde fiziksel, kültürel, ekonomik ve sosyal yönleriyle ele alınması gereken disiplinlerarası bir olgu, hükümetlerin gündeminde yönetilmesi

Anahtar

Kelimeler:

Afet,

Afet Mevzuatl,

Afet Politikasl,

Risk,

Risk Yönetimi, gereken bir politika alanı olarak yer almaktadır. Afet en genel tanımıyla, nedeni doğa kaynaklı olabildiği gibi insan faaliyetleri sonucunda da ortaya çıkan toplumlar üzerinde zarar verici ve tahrip edici etkileri olan fiziksel olaylardır. Zarar verici ve tahrip edici etkileri olan, bu fiziksel olayların etki alanının genișlemesi ve toplumsal maliyetinin giderek artmasinin en temel nedeni, alınan politika ve planlama kararlarldır. Bu açıdan değerlendirildiğinde, afetlerin kaynă̆ doğal olsa dahi sonuçları insan eliyle üretilmektedir. Afetlerin etkilerinin boyutları ve etki alanının giderek genişliyor olması afet politikalarında ve afet yönetiminde gelişmeleri de beraberinde getirmiştir. Burada afetler, ortaya çıktıktan sonra oluşan zararları telafi etmek ve gerekli acil destek mekanizmalarını hayata geçirmeye yönelik olan kriz yönetimi yaklaşımı, yerini risk yönetimi yaklaşımına bırakmaktadır. Bunun temel nedeni, ortaya çıkan zararın giderilmesinin hem ekonomik hem de sosyal maliyetinin önlemekten daha fazla olmasıdır. Diğer yandan gerek afetlerin küresel düzeyde görülme sıklığl, gerekse ortaya çıkma nedenlerinin çeşitlenmesi risk, algısının değişmesini de beraberinde getirmiștir. Bunun sonucu olarak yeniden tanımlanan risk kavramı ile risk yönetimi süreci afet politikalarında temel yaklaşım olarak uygulanmaya başlanmıştır. Bu çalışma afet ve risk kavramları arasındaki ilişkiyi ele alarak afet politikalarında risk yönetimi yaklaşımının önemini ortaya koyarak, Türkiye'de afet politikalarının uygulama araçlarından bir olarak afet mevzuatında risk yönetiminin ne şekilde ele alındığını belirlemeyi amaçlamaktadır.
\end{abstract}

Keywords:

Disaster,

Disaster

Legislation,

Disaster Policy,

Risk,

Risk Management,

\section{ABSTRACT}

Disasters have been one of the most important problem of humanity throughout history due to loss of lives and damages to the economic and social structure. It's an interdisciplinary phenomenon that needs to be addressed in the literature with its physical, cultural, economic and social aspects and a policy area nedds to be managed in the governements agenda. Disasters, in their most general definition, are physical phenomenon that have damaging and destructive effects on societies and they caused by human activities as well as nature. The main reasons for the widening of the impact area and the increasing social cost of these physical facts which have damaging and destructive effects are the policy and planning decisions. In this respect, even if the source of disasters is natural, the results are produced by human. The extent of the impacts of disasters and the widening of the impact area have led to developments in disaster policies and disaster management. The crisis management approach like emergency support mechanisms which aims to compensate the damage after disaster is being replaced the risk management approach. Its main reason is economic and social cost of recovering damages is higher than prevent them. On the other hand, both prevalance of disasters at global level and the diversification of the causes of disasters have brought a change in risk perception. As a result of this, redefined risk concept and risk management process has started to be implemented as the main approach in disaster policies. This study aims to reveal the importance of risk management approach in disaster policies by considerin the relationship between disaster and risk concepts and how risk management is addressed in disaster legislation as one of the implementation tools of disaster policies in Turkey. 


\section{GIRISS}

Dünya Bankası ve Birleşmiş Milletlerin ortak hazırladığı bir raporda belirtildiğine göre depremler, kuraklık, seller ve firtınalar gibi doğal tehlikeler insanların ihmal ve eylemleri sonucunda, ölüm ve zararları ile doğal olmayan afetlere dönüşürler (WB - UN, 2010:23). Dünya genelinde giderek daha karmaşık hale gelen, etki alanı genişleyen ve sıklığı artan afetler, meydana geldikleri yerdeki sosyo-ekonomik yapıyı önemli ölçülerde zarara uğratmaktadır. Afetlerin doğal olarak yıkıcı etkileri, toplumların afetlere karşı hassas olan unsurlarıyla birleşerek yarattıkları riskler büyük boyutlu can kayıplarına ve ekonomik zararlara yol açmaktadır. Özellikle gelişmekte olan ülkelerin gelişme düzeylerine verdikleri zararlar ve bu ülkelerde yaşayan yoksul kesimler üzerindeki yıkıcı etkileri nedeniyle afetler, insani yardım gerektiren süreçler olmaları yanında gelişme sorunu olarak algılanmaya başlanmıştır (Dilley vd., 2005:1). Bunun sonucu olarak afetlere ilişkin risk algısı ve kapsamı da değişmeye başlamış, afet politikalarına ilişsin kararlarda risk azaltma ve risk yönetimi süreçlerine odaklanılmaya başlanmıştır. Afet risklerini azaltmaya odaklanmış afet politikalarının temel araçlarından bir tanesi risk yönetimi sürecinin gereklerini güvence altına almış olan, bu bağlamda yetkili ve sorumlu kurumların belirlenmesini sağlayan hukuki düzenlemelerdir. Çalışmanın ilk bölümünde uluslararası belgeler ve raporlar çerçevesinde risk kavramı ve afet risk yönetiminin kapsamı ele alınmış, ikinci bölümünde ise afet hukuku içerisinde afet riski azaltma ve risk yönetiminin nasıl ele alınması gerektiği ve Türk afet mevzuatının risk yönetimine ilişkin düzenlemeleri değerlendirilmiştir.

\section{AFET POLITIKALARINDA RISK KAVRAMI}

Risk, kaybedilme olasılığı bulunan bir değeri temsil eden soyut bir kavramdır (Balamir, 2007:35). Afet politikalarında risk kavramı, zarar verici ve tehlike yaratan bir olayın fiziksel olarak ortaya çıkma olasılığı ile ilgili değildir. Risk, gerçekleşen zarar verici olayın afete dönüşmesini olanaklı kılan, toplumun bu olaylar karşısındaki savunmasızlığı ile ortaya çıkan bir kavramdır (Inter-American Development Bank, 2010:1). Bir diğer deyişle afet politikalarında risk, zarar verici etkileri olan olayların ortaya çıkması, yoğunluğu ya da sıklığı tarafindan belirlenemez. Zarar verici bir olayın afete dönüşmesine neden olan başlıca unsurları sosyal etkenler, politik koşullar ve ekonomik yapı oluşturmaktadır. Bu doğrultuda afet riski, belirli bir yerde ve belirli bir süre içerisinde meydana gelebilecek potansiyel can kaybı ve zarara neden olabilecek, bir toplumun yada sistemin maruz kaldığ tehlike yaratan olay karşısında savunmasızlığ 1 ve olayla başa çıkma kapasitesinin bir fonksiyonu olarak tanımlanmaktadır (UNISDR, 2019). Toplumların savunmasızlığı, özellikle afetlere açık alanlarda sosyal süreçlerle ve nüfusun zarar verici olaylar karşısındaki kırılganlığı, duyarlılığı ya da bu olaylara karşı dayanıklı olmamasıyla ilgilidir. Diğer bir deyişle, afetler, doğaları gereği sosyo-çevresel olgular olup, ortaya çıkışları sosyal olarak yaratılan risklerin sonucudur (IDB, 2010:1). Kaynak paylaşımı, arazi kullanımı, sektörel ve kentsel planlama gibi politik ve ekonomik kararlar afet riskini ortaya çıkarır. Yaşanan zarar verici olaylar sonrasında bu olaylara karşı alınan önlemler, ortaya çıkan hasarı gidermeye yönelik iyileştirme sürecine ilişkin kararlar, afet riskini etkiler. Bu çerçevede güvenli yerleşim yerlerinin oluşturulması sürecinde yapılan tercihler, arazi kullanım kararları, yer seçim kararları afet risklerini ortaya çıkaran temel etmenler olarak karşımıza çıkmaktadır. Özellikle ekonomik ve politik sistemlerin ekolojik sistemlerle giderek artan düzeyde etkileşim halinde olması sonucu riskler günümüzde sistematik bir hal almıştır.

İnsanlık tarihinde içinde bulunduğumuz dönem, dünyanın hızla değiştiği ve her açıdan birbiriyle bağlantılı hale geldiği, dolayısıyla bilinen ve bilinmeyen pek çok risk ile karşı karşıya olduğumuz bir dönemdir. Bunun sonucu olarak da yeni riskler ve bu risklerin birbiriyle bağlantısını ortaya koymak, pek çok açıdan önemli bir hal almıştır. Önceleri risk oluşturması muhtemel olan pek çok konu, bugün hali hazırda toplumların telafi etmek ve ortadan kaldırmak durumunda olduğu zararlara yol açmaktadır. Afet risklerine ilişkin değerlendirmeler, riskin kaynağına göre yapılmaktadır. Özellikle doğa kaynaklı olarak ortaya çıkan zarar verici olayların (deprem, volkanik patlamalar, vb.) sonucu olan risklere ilişkin bilgi birikimimiz oldukça fazladır. İnsanlık tarihi kadar eski deneyimlere göre, genellikle bu olaylar o anda ortaya çıkar ve kısa sürede müdahale edilebilir. Günümüzde ise, kaynağı doğa olmayan, ortaya çıkarabilecekleri sonuçlara karşı daha deneyimsiz olduğumuz başka zarar verici olaylar söz konusudur. Ekolojik ve ileri teknolojik faaliyetlerin ortaya çıkardığı sonuçlar gezegende insan yaşamı yanında tüm yaşam formlarını tehdit etmekte, yarattıkları etkiler bulundukları yer ile sınırlı kalmamakta ve uzun zaman dilimlerine yayılmaktadır (Örçen Güler, 2019:3). Küresel iklim değişikliği, biyolojik çeşitlilik ve ekosistem kaybı, ormansızlaşma, kuraklık, fiziksel çevrede değişikliklere yol açmakta ve kaynak kayıplarına sebep olmaktadırlar. Böylece oluşabilecek yeni afetlerin sebebi olabildikleri gibi afetlerin etkilerini de ağırlaştırmaktadırlar. Küresel çevre sorunlarıyla birlikte endüstriyel ve teknoloji kaynaklı kazaların pek çoğu 
AZİMLİ ÇİLINGİR, Gülcan ve ÖRÇEN GÜLER, İlke - Afet Politikalarında Risk Unsuru ve Afet Mevzuatında Risk Yönetimi

günümüzde afet risk yönetimi sürecinde değerlendirilmesi gereken çevresel güvenliği de tehdit eden riskler olarak karşımıza çıkmaktadır (Örçen Güler, 2019:4). Bu durum bizlere yeni risk grubunu küresel ölçekli ve hatta evrensel boyutlu olduğunu göstermek ve de nedensel olarak risk kaynağı ve etki alanını bir araya getirmektedir (Beck, 2014:26-36).

Risk kavramının içeriği genişleyerek afet olgusunun kapsamını değiştirmiştir. Önceleri risk kaynağı olarak algılanmayan pek çok faktörün afete dönüşebilecek düzeyde zarar verici olaylara yol açabileceğinin deneyimlenmesi sonucu afet kavramının da kapsamı genişlemiştir. Yeni riskler, insan ile birlikte diğer yaşam formlarını da tehdit ederek, insan yaşamının temeli ve pek çok ekonomik etkinliğin girdisi olan kaynakların kaybına yol açmakta, ekonomik ve toplumsal zararın boyutlarını da arttırmaktadır. Sonuç olarak afetlerin sonuçları birikimli biçimde büyüyerek belirsizleşmektedir. Afet risklerinin bu denli çeşitlenmesi ve afetlere ilişkin algıyı da değiştirmesi sonucu afet politikalarında ve afet yönetiminde risk yönetimi konusu gündeme getirmiştir. Bu bağlamda sistematik hale gelen risklerin, entegre ve yenilikçi yöntemlerle acil ve planlı biçimde azaltılmas1 gerekmektedir (UNISDR, 2019:iii).

\section{AFET POLITIKALARINDA RISKK YÖNETIMI YAKLAŞIMI}

Günümüzde afetler yalnızca doğa kaynaklı değil aynı zamanda ekonomik, teknolojik, politik kararların sonucu olarak ortaya çıkan olgular olarak karşımıza çıkmakta, sonuçlarının ekonomik ve toplumsal maliyetinin yüksek olması, afetlerin bütüncül bir yaklaşımla ele alınan politikalarla yönetilmesi gereken süreçler olduğu gerçeğini ortaya koymaktadır. Dünya genelinde giderek sayıları ve şiddeti artan ve çok çeşitli sebeplerle ortaya çıkan zarar verici olayların afetlere dönüşmesi sonucu, toplumlar çevresel, ekonomik ve sosyal açılardan büük kayıplara uğramaktadırlar. Afetlerin bu çok yönlü ve boyutlu etkileri, afet politikaları ile gelişme politikalarının birarada değerlendirilmesini gerektirmektedir. Uluslararası alanda afet yönetimi ve politikalarına ilişkin girişimlerin gelişme politikaları, özellikle de sürdürülebilir gelişme politikalarıyla bütünleşik biçimde ele alındığı görülmektedir. Bu bağlamda afet yönetimi, toplumun sağlıklı ve dengeli bir çevrede yaşamasını engelleyen afet sürecinin, tanımlanması, planlanması ve yönetilmesini kapsar (Toprak Karaman, 2017:2). Afetlerin yönetiminin ilk aşamasını oluşturan afetlerin tanımlanması ve risklerin belirlenmesi ortaya çıkabilecek kayıpları engellemek afetler sonrasındaki süreci de doğru yönetebilmek açısından oldukça önemlidir. Bu bağlamda günümüzde afet yönetimi içerisinde risk yönetimi giderek daha çok ön plana çıkmaktadır.

Afet risk yönetimi; yönetsel talimatlar ve kurumları kullanarak, strateji ve politika uygulama kapasitesi aracılığıyla, afet olasılıkları ile etkilerini azaltmaya dönük mücadele yöntemlerini geliştirmeyi kapsayan sistematik bir süreçtir (IFRC - UNDP, 2015:7). Afet risk yönetimi süreci, önleyici, zarar azaltıc1 ve afetlere hazırlıklı olmayı kapsayan bir dizi önlem ve faaliyetler aracılı̆̆ıyla, ortaya çıkan zarar verici olayların, kalıcı olabilecek etkilerini azaltmayı ya da bunlardan kaçınmayı hedefler. Bu hedefe yönelik olarak; yasal, politik, yönetsel ve kurumsal çerçevenin kurulması sürecini de içerir.

İster doğa isterse insan eliyle üretilmiş olsun, zarar verici bir olayın afet olarak değerlendirilip değerlendirilmeyeceği, neden olduğu can kaybı ile ekonomik ve toplumsal kayıplarla ölçülmektedir. 2018 yılında dünya genelinde rapor edilen 315 afet olayından 68 milyon insan etkilenmiş, 11.804 kişi yaşamını kaybetmiş ve 131.7 milyar Amerikan Doları değerinde ekonomik kayıp gerçekleşmiştir. Afetlerden etkilenen insan sayısına göre en çok Güney Asya ve Afrika kıtaları zarar görürken, ekonomik kayıp açısından Amerika kıtası en çok zarar gören bölge olmuştur (CRED, 2019:2-6). Afetlerden etkilenen insan sayısının Asya ve Afrika'da fazla olması özellikle az gelişmiş ve gelişmekte olan ülkelerde can kaybının fazla olduğu ve bu toplumların afetler karşısındaki savunmasızlı̆̆ının daha yüksek olduğunu göstermektedir. Afetler, özellikle gelişmekte olan ve az gelişmiş ülkelerde edinilmiş ekonomik unsurların ve kaynak kaybının yüksek olması nedeniyle gelişme politikalarına ve faaliyetlerine büyük zarar vermektedir. Bu kaynak kaybı halihazırda ekonomik gelişmişlik seviyesi düşük olan toplumların afetler karşısındaki savunmasızlığını arttırmakta, afetler sırasında ve afetler sonrasında yeniden inşa ve iyileşme süreçlerini de olumsuz etkileyerek, afetlerle başa çıkma kapasitesini zayıflatmaktadır. Bu bağlamda afetler; ekonomik, çevresel ve toplumsal değerler üzerindeki olumsuz etkileri ile politikalarına ve özellikle de sürdürülebilir gelişme politikalarına zarar vermektedir. Bu yönüyle afetler öncelikli olarak bir gelişme sorunudur ve afet risklerini azaltmaya yönelik uygulamalar, afet riskinin yüksek olduğu bölgelerde sürdürülebilir gelişmenin de hayata geçirilmesinde öncelikli bir yere sahiptir.

Afet politikalarında yaygın olarak uygulanmakta olan kriz yönetiminde, afetler ortaya çıktıktan sonra karşılaşılan zararla yüzleşme, bu zararın ilk etkilerini giderme ve iyileşme çalışmalarının ardından yeniden bir afetle karşılaşma durumunda, afet yönetimi sürecini etkinleştirme maliyeti; halihazırda afetler karşısında savunmasızlığı ve afetlerle başa çıkma kapasitesi düşük olan toplumlarda, büyük bir toplumsal ve ekonomik yük 
olarak karşımıza çıkmaktadır. Risk yönetimi kriz yönetiminin maliyetini, zarar verici olayların gerçekleşmesi öncesinde hazırlıklı olma sürecine ağırlık vermesi nedeniyle düşürmekte, böylece afetler sırasında toplumların direnci ve afetlerle başa çıkma kapasitesini arttırmaktadır.

Dünya genelinde afetlerin hem nicel hem de niteliksel olarak büyümesi, afetlere ilişkin algının afetlerin fiziksel olduğu kadar ekonomik, sosyal ve politik kaynakları olan olgular olarak değerlendirilmeye başlamaları ile afet riskini ve etkilerini azaltmak yönünde önlemler almak için, uluslararası alanda çeşitli girişimlerde bulunulmuştur. Uluslararası örgütlerin çabaları ile geliştirilen ve afet olgusunun sosyo-ekonomik bir yaklaşımla ele alındığ bu girişimlerde, dünya üzerinde tehlikeli doğa olaylarının sıklıkla yaşandığ 1 bölgelerde ortaya çıkabilecek afet risklerini azaltmak, afet riskini yönetmek konularında öncelikler, politika ve uygulama önerileri dikkat çekicidir.

1990'ların başında dünya genelinde pek çok bölgede yaşanan ve ağır kayıplarla sonuçlanan afetler sonucunda, afet risk yönetiminin teknik bir disiplin olması yanında afetlerin sosyo-ekonomik sonuçlarına odaklanan geniş bir bakış açısıyla ele alınmaya başlanmasına yol açarak Birleşmiş Milletler (BM) Genel Kurulu'nu harekete geçirmiştir. BM Genel Kurulu, özellikle gelişmekte olan ülkelerde ve tüm insanlık için afet riskini azaltma konusunda uluslararası düzeyde ortaklığa çağıı yaparak, 1990 ile 1999 yılları arasını Uluslararası Afet Risklerini Azaltma On Yılı olarak kabul etmiştir (Resolution, 44/236, 22.12.1989). Bu süreçte hükümetlere ulusal afet azaltma programlarının oluşturulması yanında afetlerin önlenmesi için ekonomi, arazi kullanım ve sigorta politikalarının yeniden belirlenmesi ve özellikle gelişmekte olan ülkelerde afetlerin önelenmesinin ulusal gelime programlarına entegre edilmesi tavsiye edilmiştir. 1994 yılında Japonya'da düzenlenen BM Dünya Doğal Afetleri Azaltma Konferansı, risk azaltmanın gelişme planlama ve uygulamalarında giderek artan oranda yer almasını sağlaması bakımından önemli bir girişimdir. Konferansta kabul edilen Daha Güvenli Bir Dünya İçin Yokohama Eylem Planı ve Stratejisi'nde dikkat çeken en önemli ilke; risk değerlendirmesi sürecinin, sürdürülebilir gelişmeye odaklı planlama faaliyetlerine entegre edilmesinin gerekliliğidir. BM tarafından 2005-2015 yılları arasındaki dönemde afet risklerini azaltmaya yönelik hazırlanan Hyogo Çerçeve Eylem Planı uygulama sürecine ilişkin yapılan değerlendirmede; afet riski azaltmaya yönelik politikalar ve alınacak önlemlerin gelecekte yaşanması olası kayıpların önüne geçilmesinde ekonomik ve toplumsal maliyeti azaltmaya yönelik etkin rolü doğrulanmıştır. Afet yönetiminde ekonomik ve toplumsal maliyeti azaltan niteliği ile risk yönetiminin az gelişmiş ve gelişmekte olan ülkelerdeki kazanımı sağlanmış ekonomik ve sosyal gelişmelerin, afetler nedeniyle kaybedilmesini önlemede ve sürdürülebilir gelişmenin hayata geçirilmesinde etkin bir rolü olduğu görülmüştür. Uluslararası düzeyde risk azaltma süreçlerinin uygulamaya konulması ve afet politikalarının risk yönetimine odaklanmış olmasına karşın afetlerin sayısı ve şiddetinin artarak devam etmesi, afetlere yönelik risk tanımlarının güncellenerek yapılmasını gerektirmektedir. Küresel ölçekte etkilerini giderek daha belirgin olarak görmeye başladığımız başta iklim değişikliği olmak üzere çevresel sorunlardan kaynaklanan afet risklerinin dikkat çekici boyutlara vardığı, bununla birlikte insan eliyle üretilmiş olan teknolojik ve sanayi kaynaklı afet risklerinin de dikkate alınmasının afet politikalarının etkinliğini arttıracağı öne sürülmüştür.

2015-2030 yılları arası süreçte afet risklerini azaltmaya yönelik politika ve uygulama önerilerine yer verilen Afet Risklerini Azaltma Sendai Çerçeve Eylem Planında; afet risk azaltma ve yönetimi sürecinde risk kavramına ilişkin algının oluşturulması, risklere karşı toplumun direncini arttıracak önlemlerin alınması, afet risklerini azaltma sürecinin iyileştirme ve yeniden inşa aşamalarında oluşabilecek yeni riskleri de dikkate alarak uygulamaların yapılması temel öncelikler olarak belirlenmiş olup, risk yönetiminin merkezi ve yerel düzeyde politika kararları ve hukuki düzenlemelerle desteklenmesinin önemi vurgulanmıştır. Bu süreçte devlet kurumları ile özel sektör ve sivil toplum örgütleri ile halk işbirliğinin önemine dikkat çekilerek, gerek politika kararlarında gerekse yasal düzenlemelerde yetki, görev ve sorumlulukların açıkça belirlenmesi gerektiği vurgulanmıştır.

\section{AFET POLITIKALARINDA RİSK YÖNETIMI VE HUKUKİ DÜZENLEMELER}

Afet yönetimi ve afet politikalarının en önemli araçlarından birisi olan hukuki düzenlemeler, afet riskinin azaltılmasına yönelik sürecin işleyişi açısından oldukça önemli bir yere sahiptir. Hyogo Çerçeve Eylem Planı önceliklerinde yasal düzenlemelerin önemi afet risklerini azaltmanın ulusal ve yerel öncelikler arasında yer aldığı ve güçlü bir kurumsal ve yasal temelin uygulamaların etkinliğini arttıracağg vurgulanmıştır. Afet riskini azaltmaya yönelik politikalar ile afet zararlarını azaltma yönetimine ilişkin yapının bağlantısının kurulmasında hukuk, önemli bir araçtır. Genellikle afet risklerini azaltmaya yönelik kararlar, gerek politika belgelerinde gerekse plan ve strateji belgelerinde kendine geniş bir yer bulmakta, ancak uygun hukuki düzenlemeler yapılmadığında uygulamaya geçmemektedir. 
Bu eylem planının ardından Afet Riski Azaltma Küresel Platformunun 2011 yılında Cenevre'de düzenlenen Üçüncü Toplantısında, afet riski azaltma sürecine yönelik yasal düzenlemelerin kimi eksiklikleri olduğuna değinilmiş, ulusal düzeydeki deneyimlerin iyileştirilmesi için Kızılhaç ve Birleşmiş Milletler tarafından etkin yasal düzenlemelerin çerçevesini çizen ve özellikle vurgulanması gereken konu başlıklarını belirleyen, böylece ulusal düzenlemelere yol göstermeyi amaçlayan bir rapor hazırlanmıştır (IFRC - UNDP, 2014:9). Bu rapora göre, afet politikalarında risk azaltma sürecine ilişkin hukuki düzenlemeler, kurumsal düzenlemeler açısından çok önemli bir role sahiptir. Kurumların yetki ve görevleri belirlenmiş, merkezi yönetim ve yerel yönetimler arasındaki ilişkilerin kurulmuş olması, uygulamalar açısından önemlidir. Ayrıca hukuki düzenlemeler, kurumlar ve afet riski belirleme ve azaltma sürecinde etkili rolü olan diğer paydaşlar arası koordinasyonun sağlanmasına yönelik bir araç olarak da görülebilir. Raporda dikat çeken bir unsur da afet riski azaltmaya yönelik hukuki düzenlemelerin diğer hukuk alanlarıyla ilişkisinin kurulmasının, risk azaltmada hukukun etkinliğini arttırdığına yönelik saptamadır. Bu amaçla özellikle kentsel planlama, arazi kullanımı, gecekondu alanları, çevresel konulara ilişkin hukuk belgeleriyle afet hukukunun ilişkisinin kurulması, afet politikalarına bütüncül bir yaklaşımı olanaklı kılmakta, risk alanlarının ve risk unsurlarının belirlenmesi ve riskin yönetilmesi açısından önem taşımaktadır.

Bunlara ek olarak hukuki düzenlemelerde yer verildiğinde afet risklerini azaltma sürecine olumlu katk1 sağlayan başka unsurlar da vardır. Bunların başında erken uyarı sistemleri ve risk haritalarının hazırlanması gelmektedir. Risk değerlendirme sürecinin bir parçası olarak risk haritalarının hazırlanması, afet türlerine göre sınıflandırma yapılarak ya da zarar ortaya çıkması muhtemel alanlarda ortaya çıkabilecek zarar türlerinin belirlenmesi şeklinde yapılabilir. Bu aşamaların hukuki düzenlemelerde yer alması görevli kurum ve hükümet dışı örgütlerin sorumluluklarının belirlenmesi açısından önem taşımaktadır. Hukuki düzenlemelerde yer aldığına olumlu etkileri olan bir digger konu da katılımdır. Afet politikalarına halkın katılımı, afet risklerini azaltmada önemli bir rol oynamaktadır. Gerek afetlere hazırlık aşamasında alınacak önlemler gerekse afet sonrasında yapılacaklar konusunda halkın katılımının hangi yöntemlerle hangi aşamalarda sağlanacağına ilişkin sürecin hukuki düzenlemelerde yer alması, katılımı güvence altına almak açısından önemlidir. Katılımın en önemli unsurunu dezavantajlı gruplar ve kadınlar oluşturmaktadır. Afet riski, özellikle toplumların zarar oluşturan olaylara karşı savunmasızlığı ile doğru orantılı olarak artmakta olduğundan toplumsal olarak dezavantajlı gruplar ve kadınların afet risklerini azaltmaya yönelik düzenlemelerin bir parçası olması gerekmektedir. Afetlere karşı hazırlıklı olmada halkın katılımının bir başka boyutu da halkın bilinçlendirilmesi ve afet eğitiminin gerçekleştirilmesidir. $\mathrm{Bu}$ aşamada çeşitli düzeylerdeki eğitim kurumları içerisinde gerekli eğitim içeriğinin oluşturulması ve sürekliliğin sağlanmasında hukuki düzenlemelerin rolü vardır.

\subsection{Afet Mevzuatında Risk Yönetimi}

Türkiye'de afete ve afet yönetimi örgütlenmesine ilişkin yasal düzenlemeler, meydana gelen her doğa olayının ardından, o olaya ilişkin özel bir kanunun çıkarılması yoluyla gelişmiş ve afetler meydana geldikten sonra oluşan kriz ortamında, afetlerden etkilenen insanlara bir an önce yardım edilmesi ve yaraların hızla sarılması amacıyla müdahale, iyileştirme ve yeniden yapıma yönelik tedbirlerin alınması çalışmalarına ağırlık verecek hükümlerle genişletilerek bugüne kadar gelmiştir. Sonuçta, zamanla çok dağınık ve çok çeşitli kurum ve kuruluşlar eliyle yürütülmeye çalışılan karmaşık bir yapının oluşmasına neden olmuştur (Ergünay, 2008:99; Taş ve Erdal, 2015:1075).

Türkiye'de afet yönetiminde rol alan kuruluşlar arası koordinasyon ve işbirliğini sağlama rolü, Afet ve Acil Durum Yönetimi (AFAD) Başkanlığınca yerine getirilmektedir. AFAD, bu rolüyle ülkenin genelinde afet yönetimi ile ilgili faaliyetlerin düzenlenmesi, yönlendirilmesi ile her türlü destekleme ve denetleme işlerini yerine getirmektedir. Afet ve acil durumların sebep olduğu zararlardan korunmak, afet risklerini en aza indirmek, afetlerin meydana gelmesinin ardından yapılması gereken faaliyetler hakkında tavsiye ve önerilerde bulunmak, gerçekleştirilecek politikaları belirlemek yetki ve görevi ise, Afet ve Acil Yardım Danışma Kurulu'nundur. Bu kurulla ve ihtiyaca göre oluşturulabilecek diğer danışma kurulları ile diğer paydaşlar arasındaki eşgüdüm AFAD aracılığıyla gerçekleştirilmektedir (Çilingir, 2019:64).

Kamu kurumları afet yönetiminin hayata geçirilmesinde çok önemli bir noktada yer almaktadır. Bu nedenle, kamu kurumlarının afetlerle mücadelede kritik bir görev üstlendiği ve afet yönetiminin tüm süreçlerinde kendi görev alanlarında sorumluluk alarak afetlerin etkilerini en aza indirmeye çalışmak, tüm hizmet ve yatırımlarını afet risklerini gözeterek gerçekleştirmek durumunda olduğu görülmektedir. Ayrıca, yerel yönetimler, sorumluluğundaki bölgenin ve toplumun güvenliğini ve sürdürülebilirliğini sağlamak üzere afet planlarını hazırlayıp, bu duruma göre yerel düzeyde olmak üzere plan ve stratejiler geliştirerek afet yönetimine ilişkin tüm 
süreçlerde aktif rol oynamaktadır. Paydaşlarla yerel düzeyde işbirliği yapılması noktasında da görev ve sorumlulukları mevcuttur. Afet yönetiminde başarılı sonuçlar alınabilmesi için, sivil toplum kuruluşlarının da özellikle, özerk ve esnek yapıları dikkate alındığında, afetlerle ilgili çok çeşitli alanlarda kapsamlı çalışmalar yürüterek, afet yönetiminin her sürecine katkıda bulunmaları son derece önemlidir.

Kamu kurumları, yerel yönetimler ve sivil toplum kuruluşlarının yanı sıra, akademik kuruluşlar, bilhassa bilimsel çalışmalar ve eğitim programları ile; özel sektör ise, yatırımlarını ve faaliyetlerini risk azaltma ve afete hazırlık aşamalarını güçlendirme çerçevesinde gerçekleştirerek afetlerin etkilerinin azaltılması noktasında önemli katkılar sunmaktadır. Aynı şekilde toplumun her kesimine ulaşarak afet bilincinin oluşturulmasında ve afetlerle ilgili bilgilerin paylaşılmasında önemli bir araç olan medyanın da, afetlerin sağlıklı yönetilebilmesi açısından bilgi paylaşımının doğru ve tarafsız gerçekleştirilmesi koşuluyla, önemli bir işlevi söz konusudur. Son olarak, uluslararası kuruluşlar, bilgi ve tecrübe paylaşımını sağlayan, ortak proje geliştirme imkânı sunan ve uluslararası yardımların koordinasyonunu sağlayan önemli paydaşlar olarak, afet yönetim sürecinde önemli bir boşluğu doldurmaktadır (Çilingir, 2019:64).

\subsubsection{Sayılı Umumi Hayata Müessir Afetler Dolayısıyla Alınacak Tedbirlerle Yapılacak Yardımlara Dair Kanun}

Afetin yol açtığı zararları azaltmak için, afet öncesinde, afet sırasında ve afet sonrasında yapılacak olan çalışmaların düzenlendiği, 1959 tarihli ve 7269 Sayılı "Umumi Hayata Müessir Afetler Dolayısıyla Alınacak Tedbirlerle Yapılacak Yardımlara Dair Kanun" yıllar içerisinde yapılan bir takım değişikliklerle halen yürürlüktedir. Kanun, depremin yanı sıra, büyük çaplı yangınlar, su baskınları, seller, heyelan, kaya ve çı̆̆ düşmesi gibi afetlerde; yapıların ve kamu tesislerinin genel hayata etkili olacak derecede zarar görmesi veya zarar görme ihtimali bulunması durumlarında, bu yerlerde alınacak tedbirlerle yapılacak yardımlar hakkında uygulanmaktadır.

7269 sayılı Kanun, Afet İşleri Genel Müdürlüğü çalışmalarının ana çerçevesini oluşturmaktadır. Yasaya göre afetlerden sorumlu asıl kuruluş Afet İşleri Genel Müdürlüğü ise de başta Sivil Savunma Genel Müdürlüğü, Başbakanlık Kriz Yönetim Merkezi ve Acil Durum Yönetimi Genel Müdürlüğü olmak üzere çok sayıda kurum afet olaylarına müdahil olmaktaydı ${ }^{2} .7269$ Sayılı Kanun, merkezi ve yerel düzeyde işbirliği ve koordinasyonu sağlama görevini eski adıyla Bayındırlık ve İskan Bakanlı̆̆ı'na yeni adıyla Çevre ve Şehircilik Bakanlığı'na vermişse de, Türkiye uygulamasında eşit düzlemdeki kuruluşlar arasında etkili bir koordinasyon sağlanamamış ve yapılan yasal düzenlemeler istenilen yararı sağlayamamıştır. Bunun üzerine 15.11 .1999 tarih ve 583 sayılı Kanun Hükmünde Kararname ile "Türkiye Acil Durum Yönetimi Başkanlı̆̆ı" kurulmuş ve 18.05.2000 tarih ve 600 sayılı Kanun Hükmünde Kararname ile söz konusu birimin adı "Türkiye Acil Durum Yönetimi Genel Müdürlüğü” olarak değiştirilmiş̧tir (Kemaloğlu, 2015:131).

Türkiye Acil Durum Yönetimi Genel Müdürlüğü’ne kurum ve kuruluşlar arasında işbirliği ve koordinasyonu sağlamak görevi verilmişken, 7269 Sayılı Kanun ve ilgili yönetmelikler ile de Çevre ve Şehircilik Bakanlığı'na afet yönetimine ilişkin benzer görevlerin verilmiş olmasının uygulamada sorunlara yol açtığı ifade edilmekteydi. Eşgüdüme ilişkin sorunları çözüme kavuşturmak adına, afetin meydana gelmesi durumunda acil tedbirlerin alınması konusunda, afetin yaşandığı yerin valisi yetkili kılınmıştır. Bu karışıklığın valinin eşgüdümü altında ortadan kaldırılması amaçlanmıştır. Ayrıca afetlerle ilgili önlemlerin alınmasında, belediye ve köy muhtarlarının yanı sıra, özellikle yapı ve imarla ilgili olarak uyulması gereken standartların tespiti ve bu standartların uygulanmasının takibi noktasında da yerel yönetimlere önemli görevler düşmektedir (Keleş, 2016:601).

7269 Sayılı Kanun'un en önemli özelliklerinden birisi, afetlerin sebep olacağı olumsuz sonuçları azaltmayı amaçlayan daha önce yürürlüğe konulan kanunların tümünü bir çatı altında toplayarak; afet öncesi, afet anı ve afet sonrasında yapılan çalışmaları belirli bir bütçeye bağlamasıdır. Bu bağlamda, 7269 sayılı Kanun'da 1968 yılında, 1051 sayılı Kanunla yapılan değişikliklerle afet fonu kurulması önemli gelişmelerden biridir. Ancak, afet yönetimini düzenleyen temel mevzuat olarak kabul edilen 7269 sayılı kanun ve ilgili yönetmelikler çağdaş kamu yönetimi anlayışına uygunluk açısından var olan katılım problemlerinin çözümü noktasında yeterli olamamıştır (Şengün, 2017:131).

\subsubsection{Sayılı İmar Kanunu}

3194 Sayılı İmar Kanunu'nda nüfusu 10 bini geçen her kentte imar planı yapılmasının zorunlu olduğu hükme bağlanmıştır. Mevcut düzenlemeler 1şığında, imar planlarını yapma yetkisi, mahalli müşterek nitelikte bir ihtiyaç olarak, belediye sınırları ile mücavir alanda belediyelere aittir; belediye ve mücavir alan dışında kalan 
AZİMLİ ÇİLINGİR, Gülcan ve ÖRÇEN GÜLER, İlke - Afet Politikalarında Risk Unsuru ve Afet Mevzuatında Risk Yönetimi

yerlerde yapılacak planlar ise valilik veya ilgilisince yapılır veya yaptırılır. Valilikçe uygun görüldüğü takdirde onaylanarak yürürlüğe girer. 3194 Sayılı İmar Kanunu imar plânı konusunda, yerel yönetimlerin yetkilerini bir yönüyle arttırmıştır. Şöyle ki, 3194 sayılı Yasa'nın 8/b maddesinde, nazım ve uygulama imar plânlarının, bölge plânı ve çevre düzeni plân kararlarına uygun biçimde, ilgili belediyelerce yapılması ve yaptırılması ve belediye meclisince onaylanarak yürürlüğe konulması esası getirilmiştir.

3194 Sayılı İmar Kanunu'nun 9'uncu maddesine 3394 Sayılı Kanun ile eklenen “İmar Plânlarında Bakanlı̆̆ın Yetkisi" başlığını taşıyan ilk fıkrasında ise; merkezî yönetimin gerekli gördüğg̈ hallerde yerel yönetimlerin yerine geçerek plânlamayı parsel düzeyine kadar düzenleme yetkisi verilmektedir. İmar plânı hususunda belediyelere verilen bütün yetkilerin, Başbakanın onayı ile geçici olarak Bayındırlık ve İskân Bakanına verilebileceği ile ilgili getirilen ilgili düzenleme, yerel yönetimlerin kanunla kendilerine verilen plânlama yetkilerini yerel gereksinimlere göre kullanmalarını imkansız duruma getirmektedir. Anayasa Mahkemesi, merkezi idare ile yerinden yönetim kuruluşları arasında bir denetim ilişkisi kurulacaksa, bunun idari vesayet yetkisi şeklinde olabileceğini, bu yetkinin de yerel yönetimlerin etkisini ortadan kaldıracak, etkisiz kılacak biçimde kullanılamayacağını belirttikten sonra;

"İdari vesayetin ayrı bir türü olan, yasa ile yerel yönetime bırakılan işlemlerin yerine geçme yolu ile merkezi yönetimce yapılması, ancak kapsam ve sınırlarının yasada açıç̧a belirtilmesi, bu yetkinin yerel yönetimin yasalarla kendisine verilen görevi yerine getirmekten kaçınması, bunda çok gecikmesi gibi kamu yararı ya da haklı bir nedene dayalı olması ve anayasal ölçütler dışına çıkmamasına bağlıdır”,

diyerek düzenlemenin Anayasaya aykırı olduğuna ve iptaline karar vermiştir ${ }^{3}$.

Yerel imar plânlarının düzenlenmesinin her aşamasında; insan unsurunun ve mahalli müş̧erek ihtiyaçların ön plânda yer aldığı göz önüne alındığında, Anayasanın 127. maddesindeki yerinden yönetim ilkesinden hareketle, "imar plânlaması"'nın mahalli müşterek ihtiyaçlara uygun olarak yerel yönetimler tarafindan yapılmasının gerekliliği ortaya çıkmaktadır. Kanun'da, merkezî yönetime yerel yönetimlerin yerine geçerek plânlamayı parsel düzeyine kadar düzenleme yetkisi verilmesi, yerel yönetimlerin kanunla kendilerine verilen plânlama yetkilerini mahalli müşterek ihtiyaçlara göre kullanmalarını imkansız hale getirmesine neden olacağından Anayasa Mahkemesince iptalinin önemi ortaya çıkmaktadır (Demirkol ve Baş Bereket, 2013:43).

Plansız ve çarpık yapılaşmanın önüne geçilmesi, İmar Kanunu'nun en başta gelen amaçları arasındadır. Şöyle ki, Kanun'un 1. maddesi'nde, Kanunun yerleşme yerleri ve bu yerlerdeki yapılaşmaların; plan, fen, sağlık ve çevre şartlarına uygunluğunu sağlamak amacıyla düzenlendiği ifade edilmektedir. İmar Kanunu'nun 18. maddesi çerçevesinde, hem binalı hem de binasız arazilerin, maliklerinin rızasını almaya gerek olmadan, idarece düzenlenmesi imkanı verilmektedir. İlaveten idareye, plansız yapılaşan alanların, yeniden düzenlenmesi ve özellikle yollar, yeşil alanlar, parklar, okullar gibi kamusal alanların oluşturulması firsatı da verilmektedir. Ayrıca, zaman içinde imar planlarında bir takım yetersizliklerin çıkması ve yeni ihtiyaçların belirmesi halinde, imar planlarının değiştirilmesi de mümkün hale gelmektedir (Yasin, 2005:112; Çaptuğ, 2016:58). Ancak Kanun'da, kentsel dönüşüm uygulamaları ölçeğinin ne şekilde ve nasıl uygulanacağı, bunun yanı sıra bunların uygulama süresinin ne kadar olacağı, uygulama alanında bulunması gereken teknik ve sosyal şartların durumu gibi verilere ait bilgilerin eksikliği nedeniyle yetersiz kalmaktadır (Genç, 2008:123).

\subsection{Afetler ve Kentsel Dönüşüm Mevzuatı}

Afetler ve kentleşme arasında iki yönlü bir ilişki söz konusudur. Bir yandan, kentleşme şekli, afetlerin olma olasılığını artırabilir; bu sebeple, bir ülkede nasıl bir kentleşmenin olduğu sorusunun cevabı, aynı zamanda o ülkede meydana gelebilecek afetler hakkında da bir düşüncenin oluşmasına imkan verecektir. Diğer yandan, afetler kentleşmenin şeklini etkileyebilir. Şöyle ki; kentlerin kuruluşu ve gelişimi yalnızca yazılı bilimsel bilgiler ve kurallar 1şığında gerçekleşmemiş; bilhassa ilk kentlerin oluşumunda yaşanılan deneyimler son derece önemli bir bilgi kaynağı olmuştur. İnsanlar ilk olarak bir yere yerleşmiş ve orada yapılaşma başlamış ancak sonraları meydana gelen afetler neticesinde kentin yerleşme ve yapılaşma şekli değişmiş ya da kent o yerden başka bir yere taşınmak zorunda kalmıştır. Örneğin, İstanbul çok eski dönemlerden beri depremlerin yaşandığı bir şehir olması nedeniyle, bu duruma uygun yerleşme ve yapılaşmanın gerçekleştirilmeye çalışıldığı bir kent haline gelmiştir. Aynı şekilde Van ve Erzincan kentleri de çok eski tarihlerde bugünkü yerlerinden daha aşağılarda bir yere kurulu iken, afetlerin etkisiyle daha yukarı kotlarda kurulmuştur (Şahin, 2017:258-259).

3 AYM, E.1990/38, K.1991/32, 26.9.1991: R.G. 28.11.1991 Tarih ve 21065 Say1. 
Afetleri önleme olanağı olmasa da, afetler sonucu meydana gelen kayıpları en aza indirmek mümkündür. Ülkemizde özellikle son yıllarda, acı deneyimlerle yaşanmış ve fark edilmiş olan afetlerden en önemlilerinden biri olan deprem gerçeği, kentsel dönüşüm ihtiyacını ortaya çıkaran en önemli faktörlerden biri haline gelmiştir (Özden, 2008:291). Bu açıdan, afet sonrası yaşanma ihtimali olan kayıpları en aza indirmek için, öncelikle depreme dayanıklı yapıların yapılması, depreme dayanıksız olan mevcut yapıların, özellikle konutların güçlendirilmesi ve depreme dayanıklı hale getirilmesi yönünde bir konut yenileme politikasının geliştirilmesi, izlenmesi zorunluluk arz etmektedir. Depremin yanı sıra, heyelan, sel, çı̆̆ ve kaya düşmesi gibi diğer afetlerle ilgili verilerin de toplanıp, hangi bölgelerin yerleşime uygun olduğunun tespit edilmesi, plansız yerleşimlerin önüne geçilmesi, özellikle dere yatakları içerisindeki her türlü yapı, muhtemel bir taşkında doğrudan zarar göreceğinden, dere yataklarının kesinlikle imara açılmamasının sağlanması son derece önemlidir (Geray, 2018:391).

Kentsel dönüşüm, fiziksel bir planlama çalışması olmasının yanı sıra, o yörede yaşayan nüfusun sosyoekonomik ve kültürel özellikleriyle de ilgili uygulama alanında ortaya çıkan yasal ve yönetsel sorunlarına ilişkin kapsamlı bir uygulamadır. 2011 yılında Van 'da yaşanan ve çok fazla yapının zarar görmesi ve yıkılmasıyla sonuçlanan deprem felaketinde; afet riski altındaki alanlar ile bu alanlar dişındaki riskli yapıların bulunduğu arsa ve arazilerde, fen ve sanat norm ve standartlarına uygun, sağlıklı ve güvenli yaşam çevreleri oluşturularak iyileştirme, tasfiye ve yenileme çalışmalarının yapılması ve afet riski altındaki bölgelerde yapıların dönüştürülmesi amacıyla, 6306 Sayılı "Afet Riski Altındaki Alanların Dönüştürülmesi Hakkında Kanun" yürürlüğe girmiştir.

Afet amaçlı kentsel dönüşümde uygulanacak temel ve özel bir kanun niteliğinde olan 6306 Sayılı Afet Riski Altındaki Alanların Dönüştürülmesi Hakkında Kanun, iki tür alanı kapsamaktadır. Bu alanlardan ilki, zemin yapısı sebebiyle, ikincisi üzerindeki yapılaşma sebebiyle can ve mal kaybına yol açma riski taşıyan alanlardır. 6306 Sayılı Afet Riski Altındaki Alanların Dönüştürülmesi Hakkında Kanun kapsamında dönüşüme tabi tutulacak olan yerler; riskli yapılar ve riskli alanlardır. 6306 Sayılı Kanun gereğince; riskli yapıların tespiti ile tahliyesi ve yıktırılması, riskli yapı tespiti yapmak üzere başvuran kurum ve kuruluşların lisanslandırılması, lisanslı kurum ve kuruluşların faaliyetlerinin denetlenmesi ve bu kurum ve kuruluşların ilgili mevzuatlarında öngörülen idari ve cezai yaptırımlara ilişkin işlemlerinin yürütülmesiyle görevli olmak üzere, Çevre ve Şehircilik Bakanlı̆̆ı'na bağlı olarak “Riskli Yapılar Dairesi Başkanlığı” ihdas edilmiştir.

Günümüzde fiziksel çevrenin gün geçtikçe bozulması, gecekondulaşmanın ve plansız yapılaşmanın artması, doğal ve tarihi mirasın kaybolma tehlikesi, kentin sahip olduğu kimliğin bir bütün olarak zedelenmesi, ekonomisinin kötüye gidişi ve kentsel yoksulluğun artması gibi sorunlara çözüm bulma arayışıyla kentler harekete geçmişlerse de, sorunların oldukça kapsamlı ve karmaşık bir yapıda olması, çözümün de aynı şekilde kapsamlı ve pratik olması zorunluluğunu beraberinde getirmiştir. Bu zorunluluk sebebiyle, kenti kapsayan sorunların çözümünde farklı uzmanlık alanlarının bir arada eşgüdümlü bir şekilde çalışması gerekmektedir. Riskli yapıyı tespit etme yetkisi, 6306 Sayılı Kanun'un Uygulama Yönetmeliği'nin 6. maddesine göre; Çevre ve Şehircilik Bakanlığı, Belediyeler, Çevre ve Şehircilik İl Müdürlüğü, Bakanlık tarafından yetkilendirilen Üniversiteler ve Bakanlık tarafindan lisans verilen kurum veya kuruluşlara aittir. Çevre ve Şehircilik Müdürlükleri, İl Özel İdareleri, Belediyeler, bakanlıkça yetki verilen üniversiteler ve bakanlıkça lisans verilen kurum ve kuruluşlara aittir. Uygulamada, riskli yapı tespitinin ağırlıklı olarak, Bakanlıkça lisans verilen kurum veya kuruluşlarca yapıldığı görülmektedir (Çilingir, 2019:91).

Bir yerde, alan ölçeğinde kentsel dönüşüm uygulamasına başlamak için, o yerin riskli alan ilan edilmesi zorunludur. Danıştay'ın, afete maruz kalma tehlikesi ile karşı karşıya olan bir bölgeye ilişkin olarak, 6306 Sayılı Kanun'a istinaden alınmış olan "riskli alan" kararını, ortada somut ve bilimsel veriler ışığında alınmış bir karar olmaması gerekçesiyle hukuka uygun bulmadığı yönünde verdiği kararı ${ }^{4}$;

“...uyuşmazlı̆̆a konu alanın 6306 Sayılı Kanun'da belirtilen “riskli alan” özelliğini taşıdı̆̆ına dair düzenlenen raporun alanda bulunan yapılarla ilgili olarak üzerindeki yapılaşma sebebiyle can ve mal kaybına yol açma riski taşıdı̆̆ına dair somut herhangi bir bilgi içermediği sonucuna ulaşıldı̆̆g, ayrıca alanın 1. Derece Sit Alanı olması dolayısıyla Kültür ve Turizm Bakanlığı'nın da görüşünün alınması zorunlu iken bu lazımeye uyulmadı̆̆ı anlaşılmış olduğundan, dava konusu Bakanlar Kurulu kararında hukuka uyarlık görülmemiştir” şeklindedir (Akınc1, 2017:623). 


\subsubsection{Sayılı Gecekondu Kanunu}

775 Sayılı Gecekondu Kanunu ${ }^{5}$, gecekonduların iyileştirilmesi, iyileştirme imkanı olmayanların yıkılması, gecekondularda oturanlara arsa tahsis edilmesi, teknik ve maddi açıdan yardımların gerçekleştirilmesi gibi çeşitli yollarla kentin yapılaşma ve konut sorununun çözülmesini hedeflemektedir. Ancak, ülkemizdeki gecekonduların arsa çözümünde benimsenen yanlış politika sebebiyle, Kanun, çarpık yapılaşmanın önüne geçememiş, gecekonduların tasfiyesini sağlayamamış ve yeni gecekonduların yapılmasını engelleyememiştir (Üstün, 2014:182). Dahası, kanun koyucunun gecekondulara yönelik affı ile afete dayanıklı olmayan, sağlıksız ve yetersiz binaların yasal hale gelmesi söz konusu olmuştur. Gecekondu Kanunu, afetlerin önlenmesi bir yana afetlerin meydana gelmesi ihtimalinde afet zararlarının doğması ya da artmasına ve idarenin sorumluluğunun doğmasına neden olabilecek bir düzenleme olarak karşımıza çıkmaktadır (Çilingir, 2019:106).

\subsubsection{Sayılı Toplu Konut Kanunu}

1984 tarihli Toplu Konut Kanunu, kaçak yapılaşmanın önüne geçilmesi, konutlara ilişkin sorunların çözülmesi ve daha planlı bir şehirleşmenin gerçekleştirilmesini sağlamaya yönelik kanunlardan biridir. 2985 Sayılı Kanun ile kurulması öngörülen Toplu Konut İdaresi (TOKİ)'nin kaynaklarının hangi amaçla kullanılacağı ve Kanun kapsamında yürütülecek faaliyetler Toplu Konut Kanunu'nun 2.maddesinde öngörülmüştür ${ }^{6}$. Toplu Konut Kanunu'nda yer alan amaçlara bakıldığında, bunların yalnızca altyapı ve konut gibi fiziksel sorunlara ilişkin olduğu görülmektedir. Ancak fiziksel boyutunun yanı sıra, sosyal, ekonomik ve kültürel yönü de bulunan kentsel dönüşümün gerçekleştirilmesinde, bunun tek başına yeterli olmadığı ortadadır (Yasin, 2005:115). Bu eksikliğe rağmen, Kanun'da yer alan düzenlemeler ve ilgili kanunla Toplu Konut İdaresi'ne tanınan yetkiler kentsel dönüşüm projelerinin gerçekleştirilmesinde önemli katkılar sağlamaktadır (Üstün, 2014:186; Çaptuğ, 2016:60).

Kentsel dönüşüm uygulamalarında yalnızca TOKİ değil, Çevre ve Şehircilik Bakanlığı ve belediyeler de yetkili ve görevlidir. 2985 Sayılı Toplu Konut Kanunu'nun yanı sıra, 644 Sayılı Çevre ve Şehircilik Bakanlığı'nın Teşkilat ve Görevleri Hakkında KHK ve 6306 Afet Riski Altındaki Alanların Dönüştürülmesi Hakkında Kanun kentsel dönüşüm konusunda ilgili Bakanlığa oldukça geniş yetkiler vermektedir. Riskli yapıların Bakanlıkça hazırlanacak yönetmelikle tespit edilmesi, bu tür yapılar üzerinde tasarrufların kısıtlanması, imar haklarının tapulaştırılması, kent tasarımlarının yapılması ile TOKİye ya da belediyeye yetki devri yapılması ile bu iş ve işlemlerden hangilerinin TOKİ ya da belediye aracılığıyla yapılacağının belirlenmesi, bu yetkilere örnek olarak verilebilir. Bakanlığa Kanun tarafından verilen görev ve yetkilere bakıldığında; kentsel dönüşüm faaliyetlerinde asıl yetkili olan ve TOKİ ile belediyenin üstleneceği rolün de asıl belirleyicisi olan kurum, Çevre ve Şehircilik Bakanlığı'dır (Hacıbrahimoğlu, 2013:94).

\subsubsection{Sayılı Yıpranan Tarihi ve Kültürel Taşınmaz Varlıkların Yenilenerek Korunması ve Yaşatılarak Kullanılması Kanunu}

Şehirlerin zaman içerisinde yıpranan ve eskiyen kısımlarının yeniden düzenlenmesi ve değiştirilmesi, kültürel mirasın gelecek nesillere aktarılması, kentin tarihi ve kültürel dokusunun korunması, kentsel dönüşümün önemli amaç ve işlevlerindendir. Yapıların zamanla yıpranması ve eskimesi, bir yandan güvenlik açısından bir risk oluştururken, diğer yandan hem şehirlerin kimliklerinin korunması hem de tarihi eserlerin kanunlar ile özel olarak koruma altına alınması, bunların yenilenmesi ve varlıklarının devam ettirilmesi açısından zorunluluk arz ettiğinden, kentin tarihi dokusunun korunması ve eskiyen yapıların yenilenmesi son derece önemlidir (Yasin, 2005:109). Bu gerekçelerle, 2005 y1lında kentsel dönüşüm konusunda 5366 Say1l "Yıpranan Tarihi ve Kültürel Taşınmaz Varlıkların Yenilenerek Korunması ve Yaşatılarak Kullanılması Hakkında Kanun ${ }^{7}$ ", çıkarılarak;

$5 \quad 30.07 .1966$ tarih ve 12362 say1lı Resmi Gazete.

6 Ayrıca: 2985 Sayılı Kanun'un Ek 3. maddesi’nde TOKİ Başkanlığı’na, “gecekondu bölgelerinin tasfiye edilmesi veya bu bölgelerin daha iyi duruma getirilerek yeniden kazanılması amacıla gecekondu dönüşüm projelerinin geliştirilmesi, inşaat uygulamaları ve finansman düzenlemelerinin yapılması" gibi yetkiler vermektedir.

7 05.07.2005 tarih ve 25866 sayılı Resmi Gazete. 
“şehrin yıpranan ve özelliğini kaybetmeye yüz tutmuş, Kültür veya Tabiat Varlıklarını Koruma Kurullarinca/Komisyonlarinca sit alanı olarak tescil ve ilan edilen kent bölgeleri ile bu bölgelere ait koruma alanlarının, kentin gelişimine uygun olarak yeniden inşa ve restore edilerek bu bölgelerde konut, ticaret, kültür, turizm ve sosyal donatı alanları oluşturulması, tabii afet risklerine karşı tedbirler alınması, kentin tarihi ve kültürel dokusunun yenilenerek korunması ve yaşatılarak kullanilmast"

amaçlanmıştır. 5366 Sayılı Kanun, il özel idareleri ve belediyelere, yenileme alanlarında yenileme projelerinin uygulanması sırasında afet riski taşıdığı Çevre ve Şehircilik Bakanlığı tarafından belirlenen bölgelerde, yenileme projelerinde tasfiye dahil olmak üzere, konuyla ilgili gerekli tüm düzenlemelerin yapılması ve gerektiğinde yasakların konulması konusunda geniş yetkiler sunmaktadır ${ }^{8} .5366$ Sayılı Kanun'un 6.maddesi uyarınca, Kanunun uygulanmasına ilişkin olarak; "Yıpranan Tarihi ve Kültürel Taşınmaz Varlıkların Yenilenerek Korunması ve Yaşatılarak Kullanılması Hakkında Kanunun Uygulama Yönetmeliği ${ }^{9,}$ yayımlanmıştır. İlgili Yönetmeliğin 28. ve 29. maddelerinde, afet riski taşıyan yenileme alanlarında yapılacak iş ve işlemler ile uygulanacak yasaklara dair usul ve esaslara ilişkin ayrıntılı düzenlemelere yer verilmektedir. Yönetmeliğin 28.maddesi’ ne göre; yetkili idareler, yenileme projelerinin uygulanması sırasında afet riski taşıdığı Çevre ve Şehircilik Bakanlığı'nca belirlenen bölgelerde gerekli tedbirleri alabilir, gerekli düzenlemeleri yapabilir veya gerektiğinde yasaklar koyabilir. Uygulama sırasında, bu amaca yönelik olarak, eğer mevcutsa Çevre ve Şehircilik Bakanlığı tarafından hazırlanmış olan afet etütleri esas alınır. Bu etütlerin bulunmaması ihtimalinde ise etütler yetkili idare tarafından yapılır ya da yaptırılır.

Türkiye'de afet riskleri bölgelere eşit bir şekilde dağılmadığından, bu bölgesel dengesizlikler, afetlerle mücadele ve afet risklerinin azaltılması yönünde gerçekleştirilen stratejileri olumsuz yönde etkilemektedir (Çilingir, 2019:45). Günümüzde, bu bölgesel dengesizlikler, az gelişmiş veya gelişmekte olan ülkelerin yanı sıra gelişmiş ülkelerin de temel sorunlarından biri olarak karşımıza çıkmaktadır. Bu dengesizliklerin belirlenmesi noktasında ise, o bölgede hakim olan iklim, bölgenin sanayileşme oranı, küreselleşme ve nüfus artışı gibi değişken faktörler önemli bir rol oynamaktadır. Söz konusu ortak risk faktörleriyle mücadele etmenin sağlanması açısından, tüm bölgeleri içine alan, uygun politikaların üretilmesi ve uygulanması, ayrıca bu amaçla kurumların birbirleriyle bağlantılı çalışmalar yapmaları bir gereklilik halini almaktadır (Karaca, 2011).

İlk olarak 1996 yılında yürürlüğe giren Türkiye Deprem Bölgeleri Haritası, daha sonra AFAD Deprem Dairesi Başkanlığı tarafından 18 Mart 2018 tarih ve 30364 Sayılı (mükerrer) Resmi Gazete' de yayımlanarak yenilenmiş ve 1 Ocak 2019 tarihinde yürürlüğe girmiştir. AFAD Ulusal Deprem Araştırma Programı (UDAP) tarafından desteklenen "Türkiye Sismik Tehlike Haritasının Güncellenmesi" başlıklı projeyle kamu ve üniversite işbirliğince hazırlanan harita, en güncel deprem kaynak parametrelerinin, deprem kataloglarının ve yeni nesil matematiksel modellerin dikkate alındığı ve bir önceki haritaya nazaran daha ayrıntılı bilgilerin yer aldığı bir çalışmadır. Son haritada, bir önceki haritadan farklı olarak deprem bölgeleri yerine en büyük yer ivmesi değerleri gösterilmiş ve "deprem bölgesi” kavramı ortadan kaldırılmıştır. Ancak, incelendiğinde, yeni deprem tehlike haritasının bir RİSK haritası olmadığı görülmektedir. Çünkü söz konusu haritanın bir RİSK haritası olduğunu kabul etmek için; bu tehlike haritası üzerinde yapıların ve nüfusun deprem meydana geldiğinde ne derece etkilendiğini yani depremden etkilenme durumunu bilmek, ayrıca ekonomik kayıpları saptamak ve depremin çevreye vereceği zararları hesaplayıp bu zarar ve kayıp sonuçlarını gösteren bir harita olması gerekmektedir.

AFAD'ın internet sitesinde, “deprem risk sorgulama ekranı” başlığıyla internet üzerinden Türkiye genelinde pek çok merkezde deprem afetine ilişkin risk haritaları görüntülenebilmektedir. AFAD'ın internet sitesinde yer alan deprem risk haritasında, fay hatlarının geçtiği noktalar görüntülenebilmekte ve bölgereler ilişkin deprem riskleri öğrenilebilmektedir.

85366 Sayılı Kanun (m.3).

$9 \quad$ 14.12.2005 tarih ve 26023 sayılı Resmi Gazete. 
Harita 1. Türkiye Deprem Tehlike Haritası

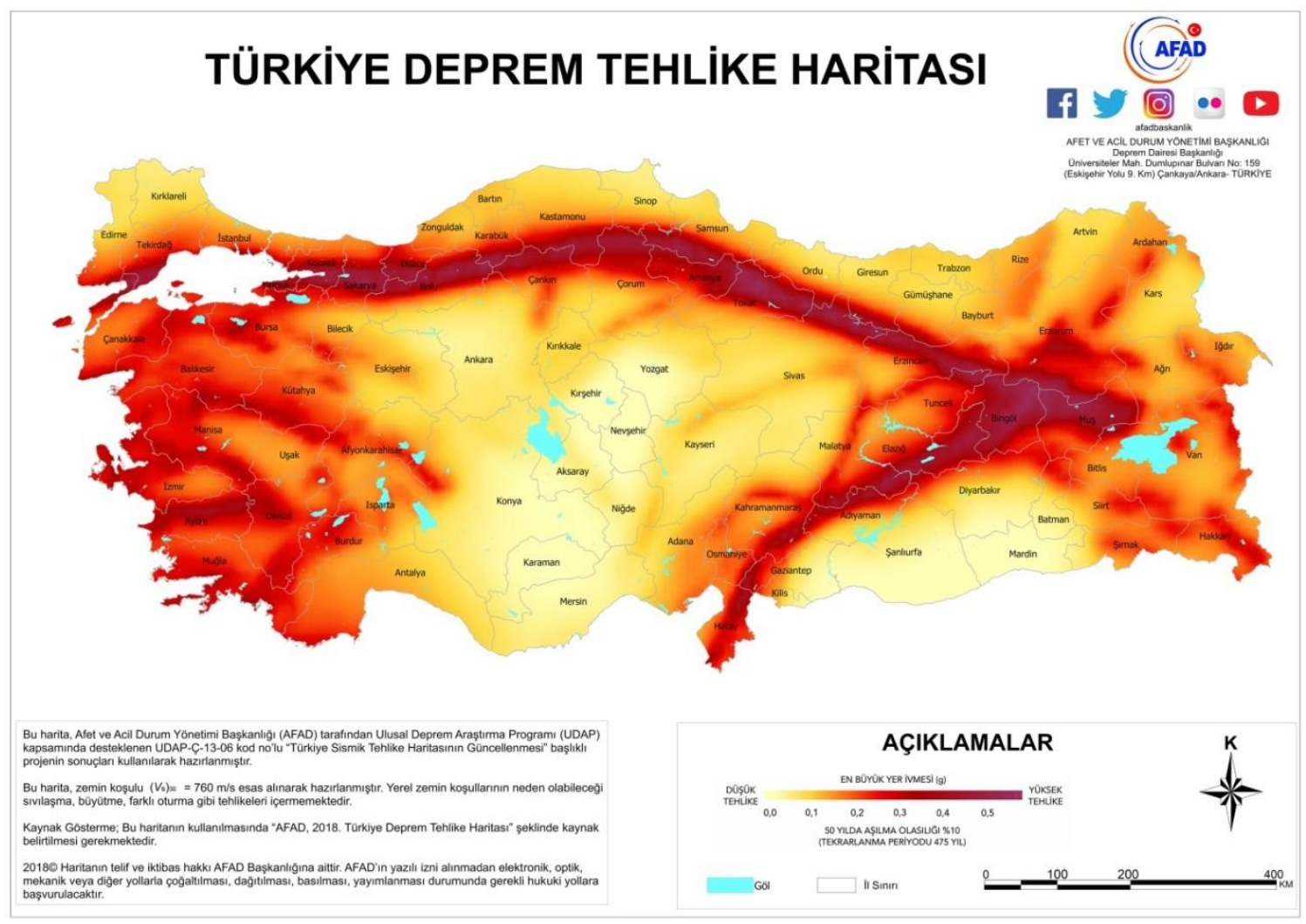

Kaynak: AFAD, https://deprem.afad.gov.tr/deprem-tehlike-haritasi, Erişim Tarihi: 01.02.2020.

Coğrafi konumu ve jeolojik yapısı göz önüne alındığında, ülkemiz, başta deprem olmak üzere çok ciddi ve şiddetli afetlerle karşılaşmaktadır. Ancak, topraklarının büyük bir kısmı deprem kuşağında yer alan ülkemizde, afetler nedeniyle meydana gelen can ve mal kayıplarının çoğunluğu da deprem afetine bağlı olarak gerçekleşmektedir. İşte, başta deprem olmak üzere, afetler sonucunda ortaya çıkabilecek can ve mal kayıplarının en aza indirilmesi için, özellikle afetler meydana gelmeden önce bir takım hazırlık çalışmalarının yapılması ve afetlerin oluşmasının önüne geçmek için her türlü önlemin alınması son derece önemlidir.

\section{SONUÇ}

Ülkemiz, coğrafi konumu ve jeolojik yapısı itibariyle, başta depremler başta olmak üzere ciddi ve şiddetli afetlere maruz kalmaktadır. Ülkemiz topraklarının büyük bir kısmı deprem kuşağında yer aldığından, afetler nedeniyle meydana gelen ölümlerin ve ekonomik kayıpların çoğunluğu da depremlere bağlı olarak gerçekleşmektedir. Afetler sonrasında ortaya çıkabilecek can ve mal kayıplarının en aza indirilmesi için, özellikle afetler meydana gelmeden önce bir takım çalışmaların, hazırlıkların yapılması ve önlemlerin alınması son derece önemlidir.

Afetlerle mücadele, bu noktada, devletin tek başına yürüteceği bir faaliyet olmayıp, aynı zamanda halkın ve sivil toplum kuruluşlarının da işbirliği ve katılımıyla gerçekleştirilmesi gereken bir faaliyettir. Özellikle, risk azaltma ve afetlere hazırlık çalışmalarına toplumun etkin olarak katılması ve bu konudaki yasal ve yönetsel düzenlemelere uyulmasının sağlanması, halkın afetlere karşı bilinçlendirilmesi ve eğitilmesi önem arz etmektedir. Öncelikle, toplumun yapı taşı olan aileler, afet bilincine sahip olmalı ve bu bilince sahip bireyler yetiştirmelidir. Sonrasında hem kendilerini ve hem de yakın çevrelerini afet riskinden korumaya sorumluluklar üstlenerek toplumun bir bütün olarak afete dirençli hale getirilmesinde katkıda bulunmalıdır.

Bu zamana kadar ülkemizde yaşanan afetlere bakıldığında, yapılan çalışmaların neredeyse tümünün afet sonrası müdahale aşamasına ilişkin olduğu görülebilir. Ancak, afet yönetiminin deprem sonrası insanları enkaz altından çıkarmak, sel baskını sonrası sel sularını tahliye etmek ya da büyük çaplı yangınlar sonrasında yangınları söndürmek gibi afetler meydana geldikten sonra bu ve bunun gibi çalışmaların yapılması anlamına gelmediği ortadadır. $\mathrm{Bu}$ nedenle, afet yönetiminde öncelik, afete müdahale çalışmalarına duyulan ihtiyacın en aza 
indirilmesini sağlamak amacıyla, afetler gerçekleşmeden önce insanları afetin risklerinden ve zararlı sonuçlarından korumak ve mevcut riskleri azaltmaya verilmelidir. Bunun sonucunda, afet risklerini azaltmaya yönelik yapılan çalışmaların, afet sonrası ortaya çıkabilecek olumsuz sonuçları büyük ölçüde etkileyeceği yadsınamaz bir gerçektir. Işte, 2000 yılı ve sonrası dönemdeki önemli yasal gelişmelerden birinin, kent yapısının yenilenmesini ve bu sayede afet risklerini azaltmayı amaçlayan kentsel dönüşümün mevzuatımızda yer alması olduğunu söyleyebiliriz.

Kentsel dönüşüm uygulamaları afet risklerini azaltma noktasında önemli bir yere sahip olsa da, ülkemiz yapıların kısa süre içerisinde afetlere, özellikle de depreme dayanıklı hale getirilmesinin zorluğu ve afetlerin önlenemeyişi, afet sonrası müdahale aşamasındaki çalışmaları ifade eden kriz yönetiminin etkinleştirilmesi ve bu aşamada yapılacak çalışmaların çok daha planlı, organize ve rasyonel bir şekilde yürütülmesini gerektirmektedir.

Afet yönetimi, toplumun katılımını gerektiren, topyekûn bir mücadele sürecini ifade etmekte ve çeşitli aşamalara ayrılmaktadır. Afet yönetiminde, afetlerin önlenmesi ve afet zararlarının azaltılması, afet sonucunu doğuran olaylara zamanında, hızlı ve etkili olarak müdahale edilmesi ve afetten etkilenen topluluklar için daha güvenli ve gelişmiş yeni bir yaşam çevresi oluşturulabilmesi ise son derece önemlidir. Bu noktada bir önceki aşamada yapılan faaliyetlerin başarısı bir sonraki aşamada yapılacak faaliyetlerin başarısını etkilemektedir. Afetlerin krizlere yol açan temel unsurlardan olduğu düşünüldügünde, meydana gelen afetin büyüklüğü ve etkisine göre afet yönetiminin kriz yönetimine dönüşebilmesi ihtimal dahilindedir.

Afet yönetiminin aslında bir risk azaltma problemi olduğu söylenebilir. 1999 yılında yaşanan ve yüzyılın felaketi olarak adlandırılan, on binlerce can kaybının yanı sıra uzun süre etkisini devam ettiren ekonomik sorunlara neden olan Marmara Depremi, risk azaltma aşamasındaki çalışmaların ne kadar önemli olduğunu acı bir şekilde gözler önüne sermiştir. Deprem sonrası, ülkemizde uygulanan afet yönetimi politikaları hakkında önemli tartışmalar yaşanmış; yasal düzenlemelerin yanında idari anlamda da yeni düzenlemeler yapılarak, afet yönetim sistemimiz, önemli ölçüde değişikliğe uğramıştır. Marmara Depremi'nden sonra, can ve mal kayıpları açısından ülkemizde meydana gelen bir diğer büyük deprem olan ve 2011 yılında Van ilinde yaşanan deprem, 1999 yılında yaşanan Marmara Depremi sonrasında, kurumsal ve yasal anlamda yapılan önemli ve köklü değişikliklerin afet yönetim sistemi üzerindeki etkilerinin değerlendirilmesinin yapılmasını sağlayan, ülkemize yaşanan ilk büyük deprem olma özelliğini de taşımaktadır.

Ülkemizde bu zamana kadar yaşanan ve büyük can ve mal kayıplarına neden olan afetler sonrası yaşanan acı tecrübeler, bize, afetlerin oluşması çoğu zaman önlenemese de zararlı sonuçlarının önüne geçilebilmesinin doğru bir devlet politikasıyla mümkün olduğunu göstermiştir. $\mathrm{Bu}$ nedenle, afetlere hazırlıklı olunması noktasında, afetlerin ne zaman ve ne şiddette olacağı bilinemese de, özellikle afete dayanıklı yapılar inşa etmek, fiziksel şartları iyileştirmek, toplumsal, ekonomik ve çevresel ihtiyaçlar doğrultusunda, kent yapılarını yeniden inşa etmek, geliştirmek ve yenilemek, bir afet meydana geldiğinde yaşanması muhtemel kayıpları en aza indirmeye yardımcı olabilecek nitelikte faaliyetlerdir. Bu açıdan kentsel dönüşüm kapsamında, riskli yapıların bulunduğu yerde dönüşüme tabi tutularak, riskli alanlarda yaşayanların yine aynı yerde ikamet etmesinin sağlanması afetlerle mücadele noktasında önemli gelişmelerden biri olarak değerlendirilebilir.

\section{KAYNAKÇA}

AKINCI, Müslüm (2017), Danıştay Kararları Işığında İdarenin Gözetim ve Denetim Görevi, Legal Yayınevi, İstanbul.

BALAMIR, Murat (2007), "Afet Politikasl, Risk ve Planlama", TMMOB Afet Sempozyumu Bildiriler Kitabı, TMMOB Yayınları, Ankara, ss.31-45.

BECK, Ulrıch (2014), Risk Toplumu Başka bir Modernliğe Doğru (Çev. Kazım Özdoğan, Bülent Doğan), İthaki Yayınları, İstanbul.

CRED (2019), Natural Disasters 2018, Cred Publications, Brussels - Belgium, https://www.cred.be/publications (Erişim Tarihi: 03.02.2020).

ÇAPTUĞ, Makbule (2016), İdare Hukuku Açısından Kentsel Dönüşüm, Seçkin Yayınevi, Ankara.

ÇİLINGİR AZIMLİ, Gülcan (2019), “Türkiye'de Afet Yönetimi ve İdarenin Sorumluluğu”, Yayımlanmamış Doktora Tezi, İstanbul Üniversitesi Sosyal Bilimler Enstitüsü, İstanbul. 
AZİMLİ ÇİLINGİR, Gülcan ve ÖRÇEN GÜLER, İlke - Afet Politikalarında Risk Unsuru ve Afet Mevzuatında Risk Yönetimi

DEMIRKOL, Selami ve BAŞ BEREKET, Zuhal (2013), "Kentsel Dönüşümün, 6306 Sayıl Yasa Kapsamında Hak ve Özgürlükler Açısından Ele Alınması”, TBB Dergisi, S.26(108), ss.23-70.

DILLEY, Maxx, CHEN, Roberst S., DEICHMANN, Uwe, LERNER-LAM, Arthur L., ARNOLD, Margaret, AGVE, Jonathan, BUYS, Piet, KJEVSTAD, Oddvar, LYON, Bradfield ve YETMAN, Gregory (2005), Natural Disaster Hotspots A Global Analysis, The World Bank, Washington D.C.

ERGÜNAY, Oktay (2008), "Afet Yönetiminde Kurumsal Yapılanma ve Mevzuat Nedir? Nasıl Olmalıdır?", CHP İstanbul Deprem Sempozyumu: İstanbul Depremini Beklerken Sorunlar ve Çözümler Bildiriler Kitabı, 20 Eylül 2008, iSTANBUL, ss.97-108.

GENÇ, Fatma Neval (2008), “Türkiye'de Kentsel Dönüşüm: Mevzuat ve Uygulamaların Genel Görünümü”, Yönetim ve Ekonomi Dergisi, S.15(1), ss.115-130.

GERAY, Cevat (2018), Kent, Yerel Yönetimler ve Toplu Konut Yazıları (Ed. Hasan Hüseyin Doğan), Palme Yayınevi, Ankara, C.1.

HACIİBRAHIMOĞLU, Nurhan (2013), “Kentsel Dönüşüm Yöntemleri”, Kentsel Dönüşüm Hukuku (Ed. Melikşah Yasin, Cenk Şahin), İstanbul Üniversitesi Sıddık Sami Onar İdare Hukuku ve İlimleri Araştırma ve Uygulama Merkezi Yayınları, İstanbul, ss.91-112.

IFRC ve UNDP (2014), Effective Law and Regulation For Disaster Risk Reduction: A Multi Country Report - Summary (Ed. Barbara Hall), Printed by TBD, New York - USA, https://www.ifrc.org/Global/Publications/IDRL/country\%20studies/summary_report_final_single_page.p df (Erişim Tarihi: 03.02.2020).

IFRC ve UNDP (2015), The Handbook on Law and Disaster Risk Reduction, IFRC Publisher, Geneva, https://www.ifrc.org/Global/Photos/Secretariat/201511/Handbook\%20on\%20law\%20and\%20DRR\%20L R.pdf (Erişim Tarihi: 03.02.2020).

IDB - INTER-AMERICAN DEVELOPMENT BANK (2010), Indicators of Disaster Risk and Risk Management: Program for Latin America and the Caribbean: Summary Report, IADB Publisher, Washington D.C., https://publications.iadb.org/en/publication/11611/indicators-disaster-risk-and-riskmanagement-program-latin-america-and-caribbean (Erişim Tarihi: 12.11.2019).

KADIOĞLU, Mikdat (2018), "Meteorolojik Afetler ve Risk Yönetimi”, Türkiye'nin Afet Yönetimi, Sosyal, Siyasal ve Yönetim Boyutuyla (Ed. Hayriye Şengün, Seçil Gül Meydan Yıldız, Binali Tercan), Palme Yayınevi, Ankara, ss.77-110.

KARACA, Ferhat, ÖZ, Halil Rıdvan ve ÖZTÜRK, İlhan (2011), "Hiyerarşik Kümeleme Analizi Yöntemi İle Türkiye'deki 81 İlin Afet ve Olağandışı Durum Riskleri Açısından Sinıflandırılması", E-Makale, http://acilafet.org/upload/dosyalar/risk_analizi_makale.pdf (Erişim Tarihi: 03.02.2020).

KARAMAN, Zerrin Toprak (2017), “Afet Yönetimine Giriş ve Türkiye'de Örgütlenme”, Bütünleşik Afet Yönetimi (Ed. Zerrin Toprak Karaman, Asuman Altay), Birleşik Matbaacılık, İzmir, ss. 1-39.

KELEŞ, Ruşen (2016), Kentleşme Politikası, İmge Kitabevi, Ankara, 15. Baskı.

KEMALOĞLU, Muhammet (2015), "Türkiye'de Afet Yönetiminin Tarihi ve Yasal Gelişimi", Akademik Bakış Dergisi, S.52, ss.126-147.

ÖRÇEN GÜLER, İlke (2019), "Afetler ve Kentler: Uluslararası Belgelerde Afet Riskleri ve Kentleşme İlişkisi", Küreselleşme ve Dönüşen Kent (Ed. Hayriye Sağır), Orion Yayınevi, Ankara, ss.233-259.

ÖZDEN, Pınar Pelin (2008), Kentsel Yenileme: Yasal - Yönetsel Boyut, Planlama ve Uygulama, İmge Yayınevi, Ankara.

ŞAHİN, Yusuf (2017), Kentleşme Politikası, Ekin Yayınları, Bursa, 6. Baskı.

ŞENGÜN, Hayriye (2017), “Afet ve Hukuk”, Afet Yönetimi (Ed. Özgür Önder, Murat Yaman), Ekin Yayınlar1, Bursa, ss.123-148.

TAŞ, Şefik ve ERDAL, Mürsel (2015), “Afet Yönetiminde Sürdürülebilirlik”, II. Uluslararası Sürdürülebilir Yapılar Sempozyumu (ISBS 2015) Bildiriler Kitabı, 28-30 May1s 2015, Ankara, https://www.academia.edu/37647850/AFET_Y\%C3\%96NET\%C4\%B0M\%C4\%B0NDE_S\%C3\%9CRD

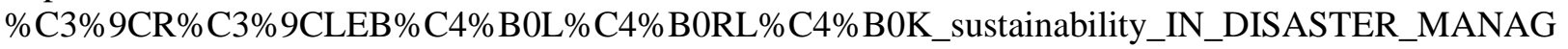
EMENT (Erişim Tarihi: 25.08.2019). 
UNISDR (2019), Global Assessment Report on Disaster Risk Reduction, Unisdr Publisher, https://www.unisdr.org/we/inform/terminology (Erişim Tarihi: 25.08.2019).

ÜSTÜN, Gül (2014), Kentsel Dönüşüm Hukuku, XII Levha Yayınları, İstanbul.

YASİN, Melikşah (2005), “Kentsel Dönüşüm Uygulamalarının Hukuki Boyutu”, Türkiye Barolar Birliği Dergisi, S.60, ss.105-137.

Türkiye Cumhuriyeti Anayasası (09.11.1982 tarih ve 17863 sayılı Resmi Gazete)

775 say1lı Gecekondu Kanunu (30.07.1966 tarih ve 12362 sayıl1 Resmi Gazete).

2985 say1l Toplu Konut Kanunu (17.03.1984 tarih ve 18344 sayılı Resmi Gazete).

3194 sayılı İmar Kanunu (09.05.1985 tarih ve 18749 say11 Resmi Gazete).

5366 sayılı Yıpranan Tarihi ve Kültürel Taşınmaz Varlıkların Yenilenerek Korunması ve Yaşatılarak Kullanılması Hakkında Kanun (05.07.2005 tarih ve 25866 sayı1ı Resmi Gazete).

6306 sayılı Afet Riski Altındaki Alanların Dönüştürülmesi Hakkında Kanun (31.05.2012 tarih ve 23809 say1l Resmi Gazete).

7269 sayılı Umumi Hayata Müessir Afetler Dolayısıyla Alınacak Tedbirlerle Yapılacak Yardımlara Dair Kanun (25.05.1959 tarih ve 10213 sayılı Resmi Gazete).

583 sayılı Başbakanlık Teşkilatı Hakkında Kanun Hükmünde Kararnamenin Değiştirilerek Kabulü Hakkında Kanunda Değişiklik Yapılmasına Dair Kanun Hükmünde Kararname (22.11.1999 tarih ve 23884 (mükerrer) say1lı Resmi Gazete).

600 sayılı Başbakanlık Teşkilatı Hakkında Kanun Hükmünde Kararnamenin Değiştirilerek Kabulü Hakkında Kanunda Değişiklik Yapılmasına Dair Kanun Hükmünde Kararname (14.06.2000 tarih ve 24079 sayıl1 Resmi Gazete).

644 sayılı Çevre ve Şehircilik Bakanlığının Teşkilat ve Görevleri Hakkında Kanun Hükmünde Kararname (04.07.2011 Tarih ve 27984 (Mükerrer) sayılı Resmi Gazete).

Bakanlar Kurulunun Yıpranan Tarihi ve Kültürel Taşınmaz Varlıkların Yenilenerek Korunması ve Yaşatılarak Kullanılması Hakkında Kanunun Uygulama Yönetmeliği (14.12.2005 tarih ve 26023 say1lı Resmi Gazete).

Çevre ve Şehircilik Bakanlığı'nın 6306 sayılı Kanunun Uygulama Yönetmeliği (15.12.2012 tarih ve 28498 say1l1 Resmi Gazete).

AYM - Anayasa Mahkemesinin 26.09.1991 tarih, E.1990/38 Esas ve K.1991/32 Sayılı Kararı (28.11.1991 tarih ve 21065 say1li Resmi Gazete). 